\title{
Comparison of the xylanolytic activities of two rumen entodiniomorphid ciliates, Epidinium caudatum and Eudiplodinium maggii
}

\author{
F Clayet 1, F Chaucheyras 1, J Sénaud 1, J Bohatier 1,2 \\ 1 Université Blaise-Pascal, laboratoire de Zoologie et Protistologie, 63177 Aubière Cedex; \\ 2 Faculté de Pharmacie, laboratoire de Biologie cellulaire, 63000 Clermont-Ferrand, France
}

Previous results have shown that some rumen entodiniomorphid ciliates present cellulolytic and hemicellulolytic activities (Bonhomme, 1988). A comparative study of xylanolytic activity, one of the main enzymatic activities, was performed in Epidinium caudatum and Eudiplodinium maggii.

The cytosolic soluble proteins were precipitated by ammonium sulfate from sonicated cell preparations of these 2 ciliates obtained free of cellulolytic and hemicellulolytic bacteria according to Bonhomme et al (1982). With non-denaturing polyacrylamide gel electrophoresis both extracts showed multiple active proteic bands against xylan and Remazol brilliant blue xylan. Preparative isoelectrofocalization showed that the active bands had acidic isoelectric points in both cases. The quantitation of reducing sugars was used to determine the enzymatic activity. The temperature for optimal activity was $45^{\circ} \mathrm{C}$ for both ciliates, and the $\mathrm{pH}$ optimal activity were 5 and 5.5 respectively for $E$ caudatum and $E$ maggii. Protein denaturation was observed $>50^{\circ} \mathrm{C}$.

The xylanolytic fractions obtained after gel filtration (Ultrogel ACA 34) and anion exchange chromatography (Biogel A) were pooled and used to determine the biochemical properties $V_{\max }$ and $K_{\mathrm{m}}$ of xylanases in both ciliates by using the Lineweaver and Burke plots (table I).

In conclusion, the physicochemical and kinetic properties of these enzymes are clearly similar but we still require information on molecular weight and potential immunological cross-reactions to complete this study.

Bonhomme A (1988) Jpn J Vet Sci 50 (2), 543547

Bonhomme-Florentin A, Fonty G, Sénaud J (1982) J Protozool 29 (2), 231-233

Table I. Biochemical properties of xylanases.

$V_{\max } \quad k_{m}$

E caudatum $85.0 \mu \mathrm{mol} / \mathrm{min} . \mathrm{mg}$ protein $0.278 \%$ E maggii $\quad 52.8 \mu \mathrm{mol} / \mathrm{min} . \mathrm{mg}$ protein $0.212 \%$ 